Original Paper

\title{
Penyuluhan, Pelatihan dan Pendampingan Pengelolaan Limbah Rumah Tangga Menjadi Pupuk Organik di Desa Kerumut Kecamatan Pringgabaya
}

\author{
Mohammad Liwa Ilhamdi ${ }^{1 *}$, Yuli Handayani ${ }^{2}$, Ayu Saputri ${ }^{3}$, Meri Anjani ${ }^{4}$, Siti \\ Safinatun Najjah ${ }^{5}$, Eva Yulianingsih ${ }^{6}$, Tri M. Rahmatullah ${ }^{7}$, Eni Marzia ${ }^{8}$, Astadwi \\ Yogasworo", Mustakim ${ }^{10}$, I Dewa Gede Wira P. ${ }^{5}$ \\ ${ }^{1}$ Pendidikan Biologi, Fakultas Keguruan dan Ilmu Pendidikan, Universitas Mataram \\ ${ }^{2}$ Jurusan Biologi, Fakultas Mipa Universitas Mataram \\ ${ }^{3}$ Jurusan Hukum, Fakultas Hukum Universitas Mataram \\ ${ }^{4}$ Jurusan Akuntansi, Fakultas Ekonomi Universitas Mataram \\ ${ }^{5}$ Jurusan Sipil, Fakultas Teknik Universitas Mataram \\ ${ }^{6}$ Jurusan Pendidikan Kimia, Fakultas Keguruan dan Ilmu Pendidikan UniversitasMataram \\ ${ }^{7}$ Jurusan Pendidikan Matematika, Fakultas Keguruan dan Ilmu Pendidikan Universitas Mataram \\ ${ }^{8}$ Jurusan Agroteknologi, Fakultas Pertanian Universitas Mataram \\ ${ }^{9}$ Jurusan Management, Fakultas Ekonomi Universitas Mataram \\ ${ }^{10}$ Fakultas Peternakan, Universitas Mataram
}

*Corresponding Author:

Mohammad Liwa

Ilhamdi, Program Studi

Pendidikan Biologi

Fakultas Keguruan dan

Ilmu Pendidikan,

Universitas Mataram,

Indonesia;

Email:

liwa ilhamdi@unram.ac.id
Abstrak: Permasalahan utama di Desa Kerumut adalah produksi sampah yang tinggi dan mencemari lingkungan. Limbah-limbah organik rumah tangga dibuang keselokan air atau dibakar sehingga menimbulkan pencemaran lingkungan seperti bau tak sedap, asap dan polusi sehingga berbahaya bagi kesehatan masyarakat. Untuk mengatasi hal tersebut maka diperlukan solusi yaitu mengolah limbah rumah tangga menjadi pupuk organik. Pupuk organik ini dapat dijual atau dimanfaatkan oleh petani untuk mendukung pertanian karena masyarakat di Desa Kerumut sebagian besar merupakan petani. Oleh karena itu, telah dilakukan program pengabdian pada masyarakat di Desa Kerumut, Kecamatan Pringgabaya, Lombok Timur. Tujuan dari kegiatan pengabdian ini adalah untuk melakukan penyuluhan, pelatihan dan pendampingan pengelolaan limbah rumah tangga menjadi pupuk organik, sehingga dapat meningkatkan hasil pertanian, ekonomi dan kesehatan masyarakat. Mahasiswa berperan dalam mengembangkan pola pemberdayaan kolaboratif melalui pendampingan dalam transfer ilmu dan keterampilannya ke masyarakat. Metode dilakukan dengan cara penyuluhan, pelatihan dan pendampingan secara langsung kemasyarakat Desa Kerumut. Hasil kegiatan ini adalah berupa pupuk kompos dari sampah organik dengan nilai tambah ekonomi yang tinggi dan fungsi pemanfaatan potensi setempat. Dari kegiatan tersebut sekitar $95 \%$ masyarakat mengerti mengenai pupuk organik selama penyuluhan, untuk kegiatan pelatihan sekitar $90 \%$ mengerti dalam cara pengolahan pupuk organik dan untuk kegitan pendampingan sekitar $30 \%$ yang benar tertarik untuk meminta mahasiswa mendampingi dalam proses pembuatannya.

Kata Kunci: Pelatihan, Penyuluhan, Pendampingan, Pemanfaatan Limbah, Pupuk Organik

\section{Pendahuluan}

Desa Kerumut adalah salah satu desa yang terletak di Kecamatan Pringgabaya, Kabupaten
Lombok Timur yang mengalami pencemaran lingkungan akibat sampah yang dihasilkan masyarakat. Sampah adalah sisa kegiatan seharihari manusia dan/atau dari proses alam yang berbentuk padat (Suyoto, 2008). Sumber sampah 
yang terbanyak berasal dari pemukiman dan pasar tradisional. Sampah pasar seperti pasar sayur mayur, pasar buah, atau pasar ikan, memiliki jenis yang relatif seragam. Sebanyak $95 \%$ berupa sampah organik. Sampah yang berasal dari pemukiman umumnya lebih beragam tetapi secara umum minimal $75 \%$ terdiri dari sampah organik dan sisanya anorganik (Latifah et al., 2012).

Laju produksi sampah di Desa Kerumut terus meningkat, tidak saja sejajar dengan laju pertumbuhan penduduk tetapi juga sejalan dengan meningkatnya pola konsumsi masyarakat. Di sisi lain kapasitas penanganan sampah yang dilakukan masyarakat maupun pemerintah daerah belum optimal. Pemerintah Desa Kerumut sampai sekarang belum bisa mengupayakan pembentukan TPA sehingga masyarakat terbiasa membuang sampah langsung di sungai yang mengalir sepanjang desa. Hal ini menyebabkan sungai tertutup sampah dan menjadi dangkal, akibatnya setiap musim penghujan desa ini selalu menjadi langganan banjir (Marliani, 2015).

Selain membuang sampah ke selokan air, masyarakat Desa Kerumut juga sering membakar sampah. Kebiasaan membakar sampah ini sudah membudaya sehingga sangat sulit untuk menghentikannya. Mereka belum menyadari bahwa jenis sampah saat ini berbeda dengan sampah jaman dulu. Jenis-jenis sampah saat ini cenderung didominasi oleh sampah sintetis kimia seperti plastik, karet, styrofoam, logam, kaca dan sebagainya. Apabila sampah-sampah tersebut dibakar maka akan mengeluarkan gas-gas beracun yang dapat membahayakan kesehatan masyarakat yang menghirupnya dan memperburuk kualitas lingkungan udara. Misalnya hasil pembakaran sampah plastik menghasilkan gas dioxin yang mempunyai daya racun 350 kali dibandingkan asap rokok. Dioxin termasuk super racun dan bersifat karsinogenik bila masuk kedalam jaringan tubuh manusia terutama saraf dan paru-paru, sehingga dapat mengganggu sistem saraf dan pernafasan termasuk penyebab kanker. Pembakaran styrofoam akan menghasilkan CFC yang dapat merusak lapisan ozon dan berbahaya bagi manusia (Subekti, 2010).

Sampah yang tidak diolah denganbaik dapat memberikan dampak negatif pada lingkungan antara lain timbulnya bau sehingga menguranggi estetika, timbulnya penyakit karena leachate/lindi merupakan sarang atau tempat vector (pembawa) penyakit. Vektor atau pembawa penyakit yang ditimbulkan dari tempat sampah adalah thypus, disentri dengan vector pembawa penyakit adalah lalat, kecoa, tikus dan lain sebagainya (Wahyono, 2011). Berdasarkan pemeriksaan posyandu bulan Februari-Maret 2019 di Desa kerumut, sebagian besar anak terkena diare, batuk, flu dan penyakit kulit sehingga rata-rata mengalami penurunan berat badan.

Untuk mengatasi permasalahan lingkungan dan kesehatan yang ditimbulkan oleh sampah, perlu dilakukan edukasi melalui pelatihan kepada masyarakat untuk mengolah sampahrumah tangga baik sampah organik secara mandiri. Melalui kegiatan ini diharapkan lingkungan menjadi lebih bersih dan warga tidak lagi membuang atau membakar sampahnya secara sembarangan. Salah satu solusi bagi penanganan sampah organik adalah pembuatan kompos (Sulistyorini, 2005 dan mulasari dkk., 2014). Untuk mempercepat pengomposan, limbahorganik perlu ditambahkan dengan Penambahan aktifator EM4 (Rahmawati dan Dony, 2014).

Pembuatan pupuk organik ini, selain diharapkan bisa mengurangi sampah organik yang menyebabkan penurunkan kwalitas lingkungan dan kesehatan, juga diharapkan bisa mengurangi kebiasaan warga Desa Kerumut yang cendrung menggunakan pupuk kimia pada lahan pertanianya. Dengan beralih ke pupuk organik, maka biaya yang dikeluarkan petani menjadi berkurang dan resiko bahaya pupuk kimia dapat dihindari. Kelebihan pupuk organik murni adalah, walaupun kuantitasnya sangat sedikit tetapi mampu memberikan pegaruh besar pada tanah yang bisa bermanfaat untuk meningkatkan produktivitas, mempercepat panen, merangsang pertumbuhan akar, batang, daun dan bunga. Hal ini diduga karena kadar haranya tepat untuk kebutuhan tanaman dan penggunaannya lebih efektif dan efisien. Sehingga hasil panen menjadi meningkat tanpa menyebabkan kerusakan tanah dan pemaparan zat kimia beracun pada hasil pertanian (Lingga, 2005). Pupuk organik yang dihasilkan juga dapat dijual untuk menambah ekonomi masyarakat. Maka dari itu, pengabdian ini diharapkan dapatmeningkatkan hasil pertanian, sanitasi lingkungan, kesehatan, dan pendapatan keluarga, melalui pengelolaan sampah menjadi pupuk organik (Hamzah dan Lestari, 2016). 


\section{Metode Pelaksanaan}

Perguruan tinggi sebagai fasilitator dan penstranfer teknologi yang dikombinasikan dengan program pemberdayaan masyarakat, akan mempercepat pencapaian program. Dalam pelaksanaan kegiatan dilakukan beberapa pendekatan yaitu:

a. Penyuluhan

Penyuluhan dilakukan untuk memberikan pengetahuan tentang limbah organik dan anorganik serta bagaimana mengolah limbah organik rumah tangga menjadi pupuk organik. Penyuluhan ini, merupakan sesi pemberian materi dilakukan secara langsung dengan bantuan media diktat dan visual. Peserta juga diberi kesempatan berdiskusi dengan pemateri.

b. Mengadakan Pelatihan mengolah bahan-bahan yang menjadi pupuk organik mulai dari pencacahan sampai fermentasi. Pelatihan dilakukan dalam berbagaitahapan :

1) Pemilahan sampah organik dan anorganik secara manual.

2) Sampah organik dicacah menjadi ukuran yang lebih kecil.

3) Sampah yang sudah berukuran kecil dimasukkan ke dalam wadah plastik dan dicampurkan dengan larutan gula dan EM4, kotoran ternak (ayam), serbuk gergaji, dedak dan sedikit air.

4) Setelah satu bulan kompos yang telah jadi kemudian dikeluarkan siap untuk dijual atau diaplikasikan ke lahan pertanian milik warga.

5) Monitoring dan evaluasi keberhasilan program.

Tahap ini dibuat untuk menilai aspek kognitif dengan menilai pemahaman dan daya serap warga Desa Kerumut terhadap materi penyuluhan dan praktek yang telah dilakukan. Aspek kognitif diamati pada awal dan akhir kegiatan dengan memberikan pre dan post test.

c. Mengadakan pendampingan proses pengolahan sampah rumah tangga menjadi pupuk organik. Pendampingan ini di rencanakan sebanyak 2 kali dirumah warga sesudah diadakannya penyuluhan dan pelatihan.

\section{Hasil dan Pembahasan}

Kegiatan penyuluhan dan pelatihan pemanfaatan limbah rumah tangga menjadi pupuk organik di Desa Kerumut Kecamatan Pringgabaya dilaksanakan sesuai dengan kebutuhan masyarakat Desa Kerumut dan kerjasama yang dibangun dapat diterima oleh masyarakat Desa Kerumut, karena sebagian besar dari penduduknya adalah petani. Pupuk anorganik yang dijual dipasaran sangat mahal, sehingga masyarakat mengalami kesulitan untuk mendapatkan pupuk karena harus mengeluar jumlah uang yang relatif besar. Untuk itu mereka sangat membutuhkan pupuk kompos untuk kegiatan usaha pertaniaan mereka. Dalam hal ini dapat memunculkan aspek pemberdayaan masyarakat dan meningkatkan motivasi masyarakat, hal ini didukung oleh sikap atau perilaku pelaksana kegiatan dilokasi pengabdian. Selain dapat mendukung pertanian dan ekonomi masyarakat, kegiatan ini juga dapat mengurangi penurunan kualitas lingkungan dan kesehatan akibat sampah warga yang dibuang atau dibakar sembarangan. Kegiatan ini dapat mendorong kemandirian masyarakat dan bermanfaat bagi masyarakat.

Pelaksanaan kegiatan diawali dengan kunjungan ke lokasi kegiatan untuk mengetahui kondisi dan permasalahan yang ada di Desa Kerumut. Berdasarkan hasil survey yang telah dilakukan, maka didapatkan hasil bahwa:

1) Desa Kerumut merupakan wilayah yang masyarakatnya dominan berprofesi menjadi petani.

2) Sebagian besar petani di Desa Kerumut menggunakan pupuk kimia di lahan pertaniannya karena menganggap pupuk organik hanya bisa menyuburkan rumput saja dan tidak bermanfaat bagi tanaman.

3) Pemerintah Desa Kerumut sampai sekarang belum bisa mengupayakan pembentukan TPA sehingga masyarakat terbiasa membuang sampahlangsung di sungai yang mengalir sepanjang Desa pada musim hujan dan membakar sampah saat kemarau.

4) Melimpahnya limbah rumah tangga disebagian besar aliran air dan areal pemukiman menyebabkan menurunnya estetika lingkungan, sungai tertutup sampah dan menjadi dangkal, sampah terbawa sampai kelaut dan merusak estetika dan ekosistem laut, drainase air sering 
tersumbat dan menyebakan luapan air saat musim hujan.

5) Karena sanitasi yang kurang baik, populasivektor peyakit seperti nyamuk, tikus dan kecoa meningkat.

Tahapan selanjutnya yaitu diskusi dengan Pemerintah Desa dan karang taruna untuk merumuskan permasalahan dan solusi menanggulangi sampah di Desa Kerumut Kecamatan Pringgabaya. Kegiatanpengabdian berlangsung melalui beberapa tahapan:

\section{Penyuluhan Program Pengabdian Kepada Warga}

Kegiatan penyuluhan dan pelatihan pembuatan pupuk organik dari sampah rumah tangga warga Kerumut dilakukan pada hari Minggu 10 Februari 2019 pukul 08.00 WITA sampai selesai, bertempat di Kantor Desa Kerumut. Sosialisasi dan pelatihan dilakukan oleh Pak Badri S.Pd dan Mahasiwa KKN-T Universitas Mataram 2019. Kegiatan sosialisasi dilakukan melalui ceramah dan diskusi. Kegiatan berlangsung dalam 2 sesi yakni Sesi pertama adalah penyampaian materi tentang sampah organik dan anorganik, bahaya penggunaan pupuk kimia, pemanfaatan sampah anorganik menjadi kerajinan tangan dan pengelolaan sampah organik menjadi pupuk organik. Kegiatan selanjutnya adalah sesi tanya jawab. Pada sesi ini banyak warga yang antusias menanyakan tentang keunggulan dari pupuk organik yang terbuat dari sampah tersebut dan ingin mengetahui cara pengaplikasiannya serta pengelolaannya. Penyuluhan mengenai pengelolaan limbah rumah tangga menjadi pupuk organik oleh narasumber ditunjukkan gambar 1 .

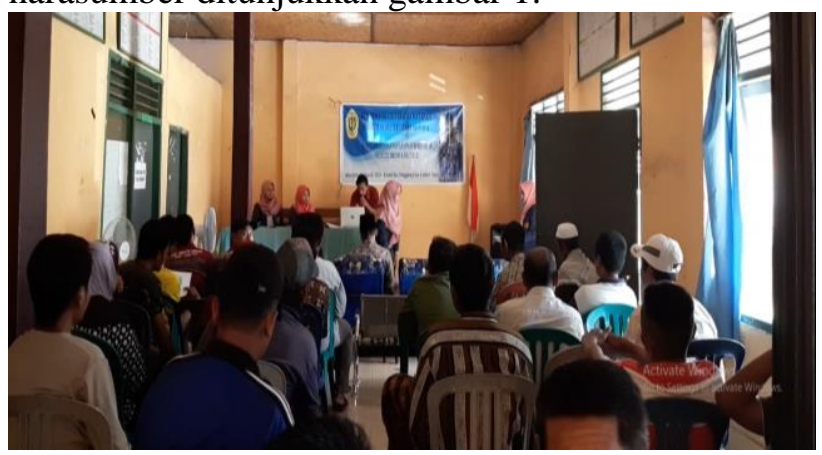

Sumber: dokumentasi pribadi

Gambar 1. Penyuluhan Materi Pemanfaatan Limbah Rumah Tangga

Berdasarkan hasil sosialisasi, para peserta terutama petani sangat antusias karena mendapatkan pengetahuan baru untuk mengolah limbah organik rumah tangga menjadi pupuk organik. Pupuk organik adalah pupuk yang berperan dalam meningkatkan aktivitas biologi, kimia, dan fisik tanah sehingga tanah menjadi subur dan baik untuk pertumbuhan tanaman (Simanungkalit $d k k, 2006$ ).

\section{Kegiatan Pelatihan Pengolahan Limbah Rumah Tangga}

Selain penyampaian materi, kegiatan ini juga dirangkai dengan pelatihan pengelolaan sampah organik menjadi pupuk organik. Sebelum pelatihan dimulai, Mahasiswa KKN Tematik Universitas Mataram 2019 terlebih dahulu menyiapkan sarana dan prasarana yang dibutuhkan untuk membuat pupuk organik seperti pelastik sampah, pisau, sampah organik, dedak, serbuk gergaji, kotoran ternak, EM4, dan air. Dalam proses pembuatan pupuk organik, limbah organik rumah tangga yang telah dikumpulkandicacah menjadi ukuran yang lebih kecil. Percepatan proses fermentasi dilakukan dengan penambahan aktivator EM4. Penggunaan aktivator EM4 dapat mempercepat proses pengomposan hingga 20 hari dibandingkan dengan penggunaan aktivator kotoran sapi dan pupuk organik komersial memakan waktu 40 hari (Marlinda, 2015).

Larutan EM4 dicampurkan dengan larutan gula. Larutan gula berfungsi untukmemperoleh energi bagi perkembangbiakan mikroorganisme yang diaktifkan selama prosespembuatan pupuk. Sebanyak $20 \mathrm{ml}$ larutan EM4 ditambahkan $10 \mathrm{gr}$ gula merah dan 1L air. Larutan yang telah dicampurkan dimasukkan ke dalam jerigen selama 24 jam. Hasil fermentasi kemudian siap diaplikasikan pada limbah organik yang telah dicacah. Limbah organik oleh mikroorganisme diubah menjadi unsur hara, $\mathrm{CO} 2, \mathrm{HO}$ dan energi (484-674 kcal/mol glukosa) (Simanungkalit dkk, 2006).

Setelah proses pencampuran bahan selesai, selanjutnya adalah proses fermentasi atau pengomposan. Bahan yang sudah dicampur dimasukkan kedalam plastik berukuran besar kemudian diikat ujungnya sehingga dalam proses pembuatan kompos ini, terjadi pengomposan anaerob yaitu proses dekomposisi bahan organiktanpa menggunakan oksigen. Setelah 1 bulan (30hari), limbah organik yang difermentasi telah berubah menjadi kompos yang warnanya hitam dan berbau tanah. Hal ini sesuai dengan 
syarat mutu kompos dari limbah organik [SNI 197030-2004]. Jika kompos baunya masih seperti bau sampah atau bau busuk berarti kompos tersebut belum matang sehingga masih memerlukan waktu lagi untuk proses pematangan. Kompos yang telah matang baunya seperti bau tanah karena materi yang dikandungnya sudah terurai dan stabil menyerupai materi tanah. Warna kompos memang menyerupai tanah hutan atau tanah pertanian yang subur dan gembur. Warna tersebut terbentuk oleh pengaruh bahan organik yang sudah stabil. Biasanya kompos yang kelembabannya rendah warnanya lebih terang sedangkan yang kelembabannya lebih tinggi, warnanya lebih gelap. Secara fisik, kompos yang telah matang bentuknya sudah hancur, tidak menyerupai bentuk aslinya. Hancurnya bentuk kompos yang matang bukan disebabkan oleh penghancuran secara fisik, misalnya oleh mesin pencacah atau mesin penggiling, tetapi disebabkan oleh penguraian alami yang dilakukan oleh mikroorganisme yang hidup di dalam kompos (Wahyono, et al, 2003).

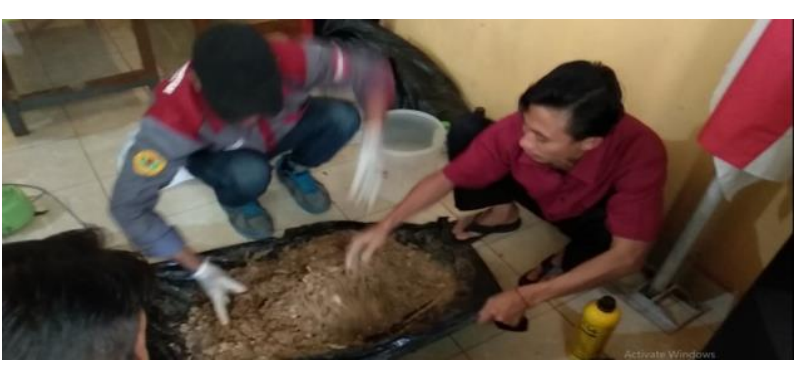

Sumber: dokumentasi pribadi

Gambar 2. Kegiatan Pelatihan Pengelolaan sampah organik menjadi pupuk organik.

Berdasarkan kegiatan pelatihan pembuatan pupuk organik yang telah dilakukan, didapatkan informasi bahwa ketertarikan masyarakat terhadap pembuatan pupuk organik sangat besar terutama petani, bahkan ada masyarakat yang ingin mendapat pendampingan dari Mahasiswa KKN Tematik Universitas Mataram dalam pembuatan pupuk organik secara mandiri di rumahnya. Antusiasme dan kinerja pemuda, masyarakat dan mahasiswa peserta KKN Tematik UNRAM 2019 di Desa Kerumut dapat dilihat pada tabel 1 di bawah ini:

Tabel 1: Penilaian Kinerja Masyarakat Desa Kerumut dan Mahasiswa KKN- T UNRAM 2019 Selama Penyuluhan dan Pelatihan

\begin{tabular}{llccccc}
\hline No & \multicolumn{1}{c}{ Skala yang di Amati } & \multicolumn{4}{c}{ Sekala Pengamatan } \\
\cline { 3 - 6 } & & 1 & 2 & 3 & 4 & 5 \\
\hline 1. & Jumlah masyarakat yang hadir berdasarkan undangan & $0 \%$ & $0 \%$ & $10 \%$ & $20 \%$ & $70 \%$ \\
2. & Ketepatan hadir dalam kegiatan penyuluhan dan pelatihan & $0 \%$ & $5 \%$ & $20 \%$ & $35 \%$ & $40 \%$ \\
3. & Kerjasama dengan sesama peserta pelatihan & $0 \%$ & $10 \%$ & $10 \%$ & $30 \%$ & $50 \%$ \\
4. & Keterlibatan dalam diskusi & $0 \%$ & $0 \%$ & $20 \%$ & $30 \%$ & $50 \%$ \\
5. & Keterlibatan dalam kegiatan pembuatan kompos & $0 \%$ & $5 \%$ & $15 \%$ & $35 \%$ & $45 \%$ \\
6. & Kemampuan komunikasi dengan sesama peserta & $0 \%$ & $5 \%$ & $20 \%$ & $30 \%$ & $45 \%$ \\
7. & Ketertarikan terhadap materi pelatihan & $0 \%$ & $0 \%$ & $5 \%$ & $45 \%$ & $55 \%$ \\
8. & Kualitas hasil atau produk yang dibuat dalam pelatihan & $0 \%$ & $0 \%$ & $15 \%$ & $35 \%$ & $50 \%$ \\
\hline
\end{tabular}

Analisis Kinerja (Performance Assessment), dengan keterangan: 1. Sangat kurang, 2. Kurang, 3. Cukup, 4. Baik, dan 5. Baik Sekali.

Masyarakat Desa Kerumut dan Mahasiswa KKN- T Universitas Mataram 2019 sangat antusias selama penyuluhan dan pelatihan, hal ini dilihat dari tabel 1. Dimana jumlah masyarakat yang hadir lebih banyak dari undangan $(90 \%)$ dan kehadirannya relatif tepat waktu $(75 \%)$ namun ada beberapa warga yang terlambat sehingga acara ditunda sekitar 10 menit. Selama pelatihan tampak kerjasama peserta pelatihan sangat baik (80\%) dalam hal ini mereka saling membantu dalam pelatihan, demikian pula keterlibatan mereka dalam diskusi dan praktek juga sangat baik (80\%). Untuk
Komunikasi sesama peserta dalam pelatihan relatif baik $(75 \%)$ dan mereka sangat tertarik $(95 \%)$ dengan pelatihan tentang pengelolan sampah menjadi pupuk organik ini karenaa selama ini mereka belum tau cara pengelolaannya. Kualitas yang dihasilkan relatif menjadi lebih baik $(85 \%)$ karena mengikuti penyuluhan dan pelatihan dengan baik.

Berdasarkan kegiatan pelatihan pembuatan pupuk organik yang telah dilakukan, didapatkan informasi bahwa ketertarikan masyarakat terhadap pembuatan pupuk organik sangat besar terutama 
petani, bahkan ada masyarakat yang ingin mendapat pendampingan dari Mahasiswa KKN Tematik Universitas Mataram dalam pembuatan pupuk organik secara mandiri di rumahnya.

\section{Pendampingan Pengolahan Limbah Rumah Tangga dan Kotoran Ternak Menjadi Pupuk Organik \\ Kegiatan pendampingan pengolahan} limbah rumah tangga dan kotoran ternak menjadi pupuk organik dilakukan atas permintaan warga yang ingin melakukan pembuatan pupuk organik secara mandiri dirumahnya. Kegiatan pendampingan ini salah satunya dilakukan di rumah salah satu warga yang terletak di Dusun Toron. Warga tersebut dulunya merupakan seorang peternak sapi dan ingin mengolah kotoran ternak yang sudah 1 tahun disimpan di belakang rumahnya

\begin{tabular}{|c|c|c|c|}
\hline No & Kegiatan Pelaksnaan & $\begin{array}{l}\text { Pengetahuan Pupuk Organik Sebelum } \\
\text { Pengabdian }\end{array}$ & $\begin{array}{l}\text { Pengetahuan Pupuk Organik } \\
\text { Sesudah Pengabdian }\end{array}$ \\
\hline 1. & Penyuluhan materi & Belum mengerti pupuk organik & Sudah mengerti pupuk organik \\
\hline 2. & Pelatihan & $\begin{array}{l}\text { Belum mengerti cara sampah menjadi } \\
\text { pupuk organik }\end{array}$ & $\begin{array}{l}\text { Sudah mengerti cara mengolah } \\
\text { sampah menjadi pupuk organik }\end{array}$ \\
\hline 3. & Pendampingan & $\begin{array}{l}\text { Belum mandiri mengolah sampah dan } \\
\text { kotoran ternak menjadi pupuk organik. }\end{array}$ & $\begin{array}{l}\text { Sudah mandiri mengolah sampah dan } \\
\text { kotoran ternak menjadi pupuk } \\
\text { organik. }\end{array}$ \\
\hline
\end{tabular}

Dari hasil pengamatan diatas dapat dilihat dalam penyuluhan materi masyarakat $95 \%$ mengerti akan pengetahuan pupuk organik, untuk kegiatan pelatihan sekitar $90 \%$ mengerti dalam cara pengolahan pupuk organik dan untuk kegitan pendampingan sekitar $30 \%$ yang benar tertarik untuk meminta mahasiswa mendampingi dalam proses pembuatannya. Namun untuk pengaplikasiannya dikarenakan waktu yang tersebut menjadi pupuk organik. Kegiatan ini didampingi oleh Pak Badri S.Pd dan Mahasiswa KKN Tematik Universitas Mataram 2019. Kegiatan ini berjalan lancar mulai dari pencampuran bahan seperti tanah, kotoran sapi, sampah organik, EM4, air, serbuk gergaji, dan dedak sampai proses fermentasi dan perlakuan selama proses fermentasi seperti penumpukan, penutupan, pembalikan tumpukan, penyiraman tumpukan, pengayakan, penyimpanan dan pengemasan kompos (Tchobanoglous, et al, 1993)

Berdasarkan pengamatan mengenai kegiatan penyuluhan sampai pendampingan di dapatkan tingkat pengetahuan masyarakat semakin bertambah. Hasil pengamatan dari pelaksanaan pengabdian ini dapat dilihat pada tabel 2 .

Tabel 3. Perbaikan Yang Diperoleh Melalui Kegiatan Pengabdian KKN-T UNRAM 2019

\begin{tabular}{llll}
\hline No & Cara Kegiatan & Sebelum Kegiatan KKN & Sesudah Kegiatan KKN \\
\hline 1. & Mengolah sampah & $\begin{array}{l}\text { Tidak diolah, dibiarkan dantidak } \\
\text { digunakan juga, dibakar dibuang } \\
\text { dan sembarangan di lingkungan. }\end{array}$ & $\begin{array}{l}\text { Sebagian masyarakat sudah bisa mengolah } \\
\text { sampah menjadi pupuk organik. }\end{array}$ \\
2. & $\begin{array}{l}\text { Memanfaatkan } \\
\text { pupuk organik }\end{array}$ & $\begin{array}{l}\text { Masyarakat tidak memanfaatkan } \\
\text { pupuk organik karena beranggapa } \\
\text { hanya menyuburkan rumput }\end{array}$ & $\begin{array}{l}\text { Sebagian petani tertarik mengolah dan } \\
\text { mengaplikasikan pupuk organik dari sampah } \\
\text { tersebut ke lahan pertaniannya }\end{array}$ \\
\hline
\end{tabular}

\section{Kesimpulan}

Kegiatan penyuluhan, pelatihan dan pendampingan berjalan dengan lancar. Masyarakat diperlukan untuk proses pembuatan pupuk lebih lama dari pada waktu KKN yang tersedia maka belum dapat diketahui untuk kegiatan pengaplikasiaanya.

Perbaikan yang diperoleh dari kegiatan KKN-T UNRAM 2019 di Desa Kerumut adalah sebagai berikut: terutama petani sangat antusias dalam kegiatan penyuluhan dan pelatihan pembuatan pupukorganik. Kegiatan penyuluhan, pelatihand an pendampingan pengelolaan limbah rumah tangga menjadi pupuk organik kepada masyarakat Desa Kerumut dapat menambah pengetahuan masyarakat 
tentang cara membuat pupuk organik dari sampah organik sehingga menciptakan lingkungan yang bersih, indah, dan sehat serta menjadi nilai tambah ekonomi, menurunkan biaya pertanian serta meningkatkan hasil pertanian warga Desa Kerumut. Dari hasil pengamatan selama penyuluhan, $95 \%$ masyarakat yang hadir dalam kegiatan memahami akan pengetahuan pupuk organik, untuk kegiatan pelatihan sekitar $90 \%$ masyarakat yang hadir dalam kegiatan memahami dalam cara pengolahan pupuk organik dan untuk kegiatan pendampingan sekitar $30 \%$ yang tertarik untuk meminta mahasiswa mendampingi dalam proses pembuatannya.

\section{Saran}

Berdasarkan hasil kegiatan pengabdian yang telah dilakukan berjalan dengan baik dan lancar. Maka untuk kedepannya diharapkan penyuluhan, pelatihan dan pengelolaaan pembuatan pupuk organik dapat dilaksanakan oleh desa-desa lain yang belum melaksanakan program tersebut serta dapat dilakukan secara berkelanjutan oleh Mahasiswa KKN-T selanjutnya.

\section{Ucapan Terimakasih}

Ucapan terimakasih disampaikan kepada Universitas Mataram yang telah memberikan kesempatan dan wadah kepada mahasiswa Universitas Mataram tahun 2019 untuk melakukan KKN Tematik di Desa Kerumut. Ucapan yang sama disampaikan kepada Pemerintah Desa Kerumut, Karang Taruna, masyarakat Desa Kerumut dan Pak Badri S.Pd., yang sudah bersedia menjadi pemateri

\section{Daftar Pustaka}

Hamzah, A \& Lestari, S.U. 2016. Rumah Pangan Lestari Organik sebagai Solusi Peningkatan Pendapatan Keluarga. J.Akses Pengabdian Indonesia, 1(1): 6572.
Latifah R. N, Winarsih, Rahayu, Y. S. 2012. Pemanfaatan Sampah Organik sebagai Bahan Pupuk Cair untuk Pertumbuhan Tanaman Bayam Merah. Jurnal Lentera Bio 1:139-144.

Marliani, N. 2015. Pemanfaatan LimbahRumah Tangga (Sampah Anorganik) Sebagai Bentuk Implementasi Dari Pendidikan Lingkungan Hidup. Formatif: Jurnal Ilmiah Pendidikan MIPA, 4(2).

Marlinda. 2015. Pengaruh Penambahan Bioaktivator EM4 dan Promi dalam Pembuatan Pupuk Cair Organik dari Sampah Organik Rumah Tangga. Jurnal Konversi. 4(2):1-6.

Mulasari, S. A., Husodo, A. H., \& Muhadjir, N. 2014. Kebijakan pemerintah dalam pengelolaan sampah domestik. Kesmas: National Public Health Journal, 8(8): 404-410.

Rahmawanti, N., \& Dony, N. (2014). Pembuatan Pupuk Organik Berbahan Sampah Organik Rumah Tangga dengan Penambahan Aktivator EM4 di Daerah Kayu Tangi. Jurnal Ziraa'ah, 39(1): 1-7.

Simanungkalit, R. D. M, Suriadikarta, D. A, Saraswati, R. Setyorini, D. \& Hartatik, W. 2006. Pupuk Organik dan Pupuk Hayati (Organik Fertilizer dan Biofertilizer). Balai Besar Litbang Sumberdaya Lahan Pertanian

SNI. 2004. Spesifikasi kompos dari sampah organik domestik. ICS 12.030 .40 Badan Standardisasi Nasional

Subekti, S. 2010. Pengelolaan Sampah Rumah Tangga 3r Berbasis Masyarakat. Fakultas Teknik, Teknik Lingkungan Universitas Pandanaran Semarang.

Sulistyorini, L. 2005. Pengelolaan sampah dengan cara menjadikannya kompos. Jurnal Kesehatan Lingkungan, 2(1).

Suyoto, Bagong. 2008. Rumah Tangga Peduli Lingkungan. Jakarta: Prima Media.

Tchobanoglous, G., H. 1993 Theisen and S Vigil, Integrated Solid Waste Management, Engineering Principlesand Management Issues, Mc. Graw Hill, Inc., USA

Wahyono, S. 2011. Pengolahan sampah organik dan aspek sanitasi. Jurnal Teknologi Lingkungan, 2(2). 
Wahyono, S., Sahwan F. L. \& Suryanto, F. 2003. Pengomposan Sampah Kota Sistem Windrow Bergulir. Pusat Teknologi Lingkungan, BPPT.

Yuwono, T. 2006. Kecepatan Dekomposisi dan kualitas Kompos Sampah Organik. Jurnal Inovasi Pertanian, 4(2). 